J. Dairy Sci. 98:3071-3078

http://dx.doi.org/10.3168/jds.2014-8466

(C) American Dairy Science Association ${ }^{\circledR}, 2015$.

\title{
Bovine subclinical intramammary infection caused by coagulase-negative staphylococci increases somatic cell count but has no effect on milk yield or composition
}

\author{
T. Tomazi, J. L. Gonçalves, J. R. Barreiro, M. A. Arcari, and M. V. dos Santos ${ }^{1}$ \\ Department of Animal Nutrition and Production, School of Veterinary Medicine and Animal Science, University of Sao Paulo, \\ Pirassununga 13635-900, Brazil
}

\begin{abstract}
The aim of this study was to evaluate the effect of subclinical intramammary infection (IMI) caused by coagulase-negative staphylococci (CNS) as a group and by specific CNS species on milk yield and composition and somatic cell count (SCC) of dairy cows. Selection of cows with IMI caused by CNS was performed by microbiological cultures of composite samples collected from 1,242 dairy cows distributed in 21 dairy herds. After selection of cows, milk yield was measured and milk samples were collected at the mammary quarter level (i.e., 1,140 mammary samples collected from 285 cows) for analysis of milk composition and SCC. In total, 108 isolates of CNS were identified at the species level by PCR-RFLP analysis. Forty-one pairs of contralateral mammary quarters, with and without IMI, were used to evaluate the effect of CNS on milk yield and composition. Mammary quarters infected with CNS had higher geometric mean SCC (306,106 cells/mL) than noninfected contralateral mammary quarters $(62,807$ cells $/ \mathrm{mL}$ ). Intramammary infection caused by CNS had no effect on milk yield or on contents of fat, crude protein, casein, lactose, total solids, and solids-not-fat. Staphylococcus chromogenes was the most prevalent CNS species in this study and the only species that allowed within-cow evaluation. The IMI caused by $S$. chromogenes increased SCC but had no effect on milk yield and composition at the quarter level. In conclusion, subclinical mastitis caused by CNS increased the SCC but had no effect on milk yield and composition of dairy cows.
\end{abstract}

Key words: coagulase-negative staphylococci, milk yield and composition, subclinical mastitis, minor pathogen

Received June 9, 2014.

Accepted January 12, 2015.

${ }^{1}$ Corresponding author: mveiga@usp.br

\section{INTRODUCTION}

Mastitis is the most prevalent disease in dairy cows and is responsible for major dairy industry losses, especially in the subclinical form of mastitis. During the last few decades, specific programs for prevention and control of mastitis have resulted in reduction of IMI caused by major pathogens. Simultaneously, studies have shown an increase in incidence of mastitis caused by minor pathogens, mainly CNS (Pyörälä and Taponen, 2009). Currently, CNS is one of the most prevalent groups of microorganisms causing mastitis in dairy cows (Taponen et al., 2006; Thorberg et al., 2009).

The effect of IMI caused by CNS on milk yield and composition remains inconclusive. Some studies have classified CNS as an important cause of bovine mastitis with the potential to reduce milk yield (Timms and Schultz, 1987; Gröhn et al., 2004). In contrast, other studies classified these microorganisms as minor pathogens with no effect on milk yield or quality (Paradis et al., 2010). Recently, because CNS-infected cows presented higher milk yield than noninfected cows, it was suggested that cows infected with CNS would be less susceptible to natural infections caused by major pathogens (Schukken et al., 2009; Paradis et al., 2010; Piepers et al., 2013). The variability among studies on the effect of CNS on milk yield and composition might be attributed to differences in study design and challenge conditions.

Most studies that have evaluate the effect of IMI caused by CNS on milk yield and composition considered CNS as a group of bacteria; however, approximately 16 different CNS species are frequently isolated from cows with mastitis (Capurro et al., 2009; Tomazi et al., 2014). Most IMI caused by CNS remain subclinical and usually result in mild to moderate increases in SCC compared with mastitis caused by major pathogens (Piepers et al., 2013).

Some CNS species, such as $S$. chromogenes and $S$. epidermidis, are more adapted to the cow's mammary gland and seem to use it as a reservoir and infection source (Piessens et al., 2012; Fry et al., 2014). In addi- 
tion, cows with IMI caused by $S$. chromogenes, $S$. simulans, and S. xylosus had SCC similar to that observed in IMI caused by S. aureus (Supré et al., 2011). Thus, the epidemiological diversity among CNS species might warrant microbiological identification of this group of bacteria to the species level.

Milk yield losses due to CNS mastitis might be underestimated when the yield of infected cows is compared with the milk yield of noninfected cows rather than with their own potential production at the time of IMI (Pyörälä and Taponen, 2009). To our knowledge, no study has reported the effect of IMI caused by CNS on milk yield and composition by comparison of healthy and infected contralateral mammary quarters. This comparative method could minimize confounding factors at both the cow and herd levels, such as cow's immune status at the time of infection, management systems, or environmental challenge. The use of this experimental design may be more reliable for evaluation of the CNS effect on milk quality and yield.

Therefore, the objectives of this study were (1) to determine the effect of CNS subclinical IMI at group and species levels on milk yield and SCC by evaluation of contralateral (healthy and infected) mammary quarters; and (2) to determine the effect of subclinical CNS IMI on concentrations of milk fat, protein, lactose, casein, TS, and SNF.

\section{MATERIALS AND METHODS}

\section{Herd and Cow Selection and Sample Collection}

Twenty-one dairy herds located in the midwest portion of São Paulo State, Brazil, were enrolled in this study during a 14-mo sample collection period. To be enrolled in the study, herds had to meet the following requirements: (1) good cow identification and recording system, and (2) accomplishment of proper milking management and mastitis control practices, which includes disposal of first streams of milk, disinfection of teats before and after milking using disinfectant solutions, drying teats with disposable towels, and treatment of clinical mastitis cases.

Cows were enrolled in the study based on microbiological cultures performed after 2 milk sample collections. First, composite milk samples (milk from all mammary quarters) were collected aseptically from each cow for screening of cows with CNS IMI. Sample collection procedures for microbiological culture followed the guidelines of the National Mastitis Council (Oliver et al., 2004). After microbiological culture of the first milk sample, cows with positive isolation of CNS were individually sampled at the quarter level within a period of $14 \mathrm{~d}$. During the second sample collection, milk yield was measured at the quarter level, and quarter milk samples were collected for microbiological culture and for analyses of composition and SCC.

For average quarter milk yield and collection of quarter milk samples for analyses of composition and SCC, mammary quarters were milked individually using a bucket milking system (Intermaq Milking Systems, Porto Alegre, Brazil), which was connected to the milking machine vacuum line. The equipment included a pulsator and a cluster of 4 liners connected to individual silicone tubing equipped with valves for vacuum release. This milking system allowed the milk to flow from each mammary quarter to a 4-compartment stainless steel bucket. Quarter milk yield was stirred and weighed, and milk samples ( $40 \mathrm{~mL})$ were collected into plastic tubes containing Bronopol (Microtabs II, D\&F Control Systems Inc., Norwood, MA) as preservative (0.05 g/100 mL milk) according to International Dairy Federation (IDF, 1995). Quarter milk samples were kept refrigerated $\left(4-7^{\circ} \mathrm{C}\right)$ and submitted to analysis of milk composition and SCC within 3 to $5 \mathrm{~d}$.

\section{Laboratory Analysis}

Cultures. Microbiological cultures of milk samples were performed following the guidelines of National Mastitis Council (Hogan et al., 1999). Briefly, a 0.01-mL loop of milk was spread on a blood agar plate (BBLBecton Dickinson and Co., Le Point de Claix, France) and incubated aerobically at $37^{\circ} \mathrm{C}$. Phenotypic features were examined after 24,48 , and $72 \mathrm{~h}$, and the isolates were identified as CNS based on colony morphology, Gram staining, and catalase and coagulase test results (Oliver et al., 2004). A milk sample was defined as contaminated if more than 2 different colony types were present in the agar plate. Coagulase-negative staphylococci pure cultures were stored at $-25^{\circ} \mathrm{C}$ in $1 \mathrm{~mL}$ of brain heart infusion broth (BBL-Becton Dickinson and Co.) supplemented with $10 \%$ glycerin until further analysis.

Molecular Identification. Coagulase-negative staphylococci were genotypically identified at the species level using PCR-RFLP analysis of a partial groEL gene sequence (Santos et al., 2008; Tomazi et al., 2014). Briefly, all isolates were inoculated on fresh agar plates for 18 to $24 \mathrm{~h}$ of incubation at $37^{\circ} \mathrm{C}$ to check for isolate purity. The extraction of genomic DNA from pure cultures of CNS isolates was performed using an Illustra bacteria genomicPrep Mini Spin Kit (GE Healthcare, Chalfont St. Giles, UK). After extraction, bacterial DNA was submitted to precipitation by 2 ethanol washes according to Sambrook and Russell (2001). The quality of extracted DNA was evaluated by measuring absorbance at 260 and $280 \mathrm{~nm}$ using a NanoDrop 2000 
spectrophotometer (Thermo Scientific, Wilmington, $\mathrm{DE}$ ), and the DNA samples were stored at $-80^{\circ} \mathrm{C}$ until PCR amplification. The groEL degenerate primers used to amplify a 550-bp groEL gene fragment were H279A [5'-GAIIIIGCIGGIGA(TC)GGIACIACIAC-3'] and H280A [5'-(TC)(TG)I(TC)(TG)ITCICC(AG) AAICCIGGIGC(TC)TT-3'], as described previously by Goh et al. (1997). The presence of a PCR product was confirmed by agarose gel electrophoresis. The RFLP analysis, using $A l u \mathrm{I}$ restriction endonuclease, was carried out as described by Santos et al. (2008). A double digestion with the restriction enzymes HindIII (10 U) and PvuII (10 U) was performed for identification at the species level of $S$. chromogenes, $S$. hyicus, and $S$. capitis, following the same protocol. The size of digested bands was determined by measuring distance from the center of the well to the center of the band and comparing it with the 25-bp DNA ladder (Invitrogen Life Technologies, São Paulo, Brazil). In addition, reference strains were used as positive control and analyzed by the same molecular protocol for comparison with the isolated CNS species (Table 1).

Milk Composition and SCC. Concentrations of milk fat, protein, lactose, casein, TS, and SNF were determined by infrared absorption system, using MilkoScan FT+ (Foss Electric, Hillerød, Denmark). The SCC was determined by flow cytometry using a Fossomatic FC (Foss Electric).

\section{Definition of IMI}

An IMI was determined when both milk samples collected from the same cow in 2 consecutive sample collections performed within $14 \mathrm{~d}$ were microbiologically positive for CNS, and with at least 10 grown colonies (1,000 cfu/mL; Andersen et al., 2010; Dohoo et al., 2011). Conversely, milk samples were considered negative (noninfected quarter) when no isolation of mi- croorganisms (within $72 \mathrm{~h}$ of incubation) was observed in the 2 microbiological cultures, and when SCC was $<200,000$ cells/mL (Schukken et al., 2003).

\section{Statistical Analysis}

The effects of subclinical IMI caused by CNS as a group or by specific CNS species on quarter milk yield, composition, and SCC were evaluated. The milk yield, composition, and SCC of infected quarters were compared with the same variables from noninfected contralateral quarters by a strip-plot design (front or rear half of the udder were the strips, and left or right glands within a strip were the plots). This was achieved by splitting the anterior and posterior mammary quarters in halves. Thus, the left and right contralateral mammary quarters were compared within half and cow. In other words, if the left front quarter was infected with CNS, the right front quarter was used as control, and the same was done with the rear mammary quarters. The mixed model was

$$
\begin{gathered}
\mathrm{Y}=\mu+\mathrm{IMI}+\mathrm{H}(\mathrm{IMI} \times \mathrm{H}) \\
+\{[\mathrm{C}+(\mathrm{C} \times \mathrm{H})+[\mathrm{IMI} \times \mathrm{C}(\mathrm{H})]\}+\mathrm{e},
\end{gathered}
$$

where $\mathrm{Y}$ is the dependent variable; $\mu$ is the overall mean; IMI and $\mathrm{H}$ are the fixed effects of variables, wherein IMI is the presence or absence of subclinical mastitis caused by $\mathrm{CNS}$ and $\mathrm{H}$ is the contralateral quarters (right or left) within cow; IMI $\times \mathrm{H}$ is the interaction between the fixed effects; $\mathrm{C}$ is the random effect of cow; and e is the random error term.

Somatic cell counts were converted to linear scores (LS) by the formula: $\mathrm{LS}_{\mathrm{SCC}}=\log _{2}(\mathrm{SCC} / 100)+3$ (Schukken et al., 2003). The average SCC of both uninfected and infected mammary quarters identified at the species level were presented as geometric mean, which

Table 1. Type and reference strains used as control in the study

\begin{tabular}{lll}
\hline Species & Strain & Origin \\
\hline Staphylococcus aureus & ATCC 12600 & Human, pleural fluid \\
Staphylococcus capitis & ATCC 27840 & Human, skin \\
Staphylococcus caprae & ATCC 35538 & Goat, milk \\
Staphylococcus cohnii & ATCC 29974 & Human, skin \\
Staphylococcus chromogenes & ATCC 43764 & Pig, skin \\
Staphylococcus epidermidis & ATCC 14990 & Human, nose \\
Staphylococcus haemolyticus & ATCC 29970 & Human, skin \\
Staphylococcus hominis & ATCC 27844 & Human, skin \\
Staphylococcus hyicus & ATCC 11249 & Pig, epidermitis \\
Staphylococcus saprophyticus & ATCC 15305 & Human, urine \\
Staphylococcus sciuri & ATCC 29061 & Squirrel, skin \\
Staphylococcus simulans & ATCC 27848 & Human, skin \\
Staphylococcus xylosus & ATCC 29971 & Human, skin \\
Staphylococcus warneri & ATCC 10209 & Snake, antibiosis indicator \\
\hline
\end{tabular}


Table 2. Milk yield, milk composition, and SCC of mammary quarters with IMI caused by CNS as a group and at species level

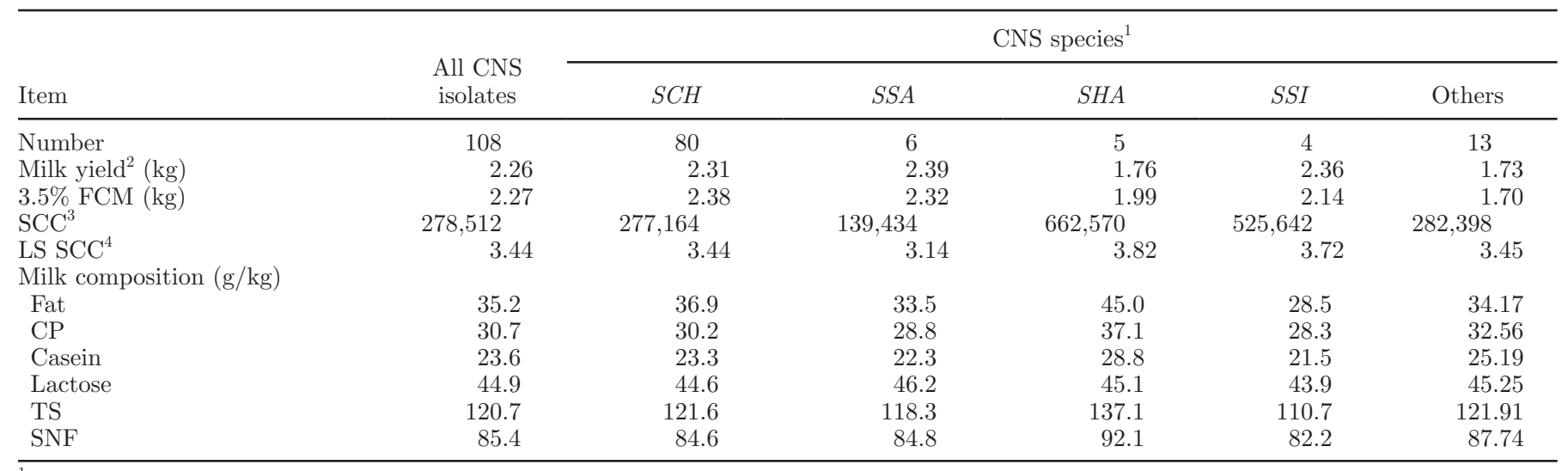

${ }^{1}$ SCH = Staphylococcus chromogenes $;$ SSA = Staphylococcus saprophyticus; SHA = Staphylococcus haemolyticus; SSI = Staphylococcus simulans; other species: Staphylococcus xylosus $(\mathrm{n}=3)$, Staphylococcus capitis $(\mathrm{n}=2)$, Staphylococcus epidermidis $(\mathrm{n}=2)$, Staphylococcus sciuri $(\mathrm{n}=1)$, Staphylococcus cohnii $(\mathrm{n}=1)$, and Staphylococcus hyicus $(\mathrm{n}=1)$.

${ }^{2}$ Quarter milk yield $(\mathrm{kg})$ from a single milking.

${ }^{3}$ Average geometric mean SCC (cells $/ \mathrm{mL}$ ).

${ }^{4}$ Natural logarithm-transformed SCC.

was calculated as the $n$th root of the product of all SCC values. Statistical models were analyzed using the MIXED procedure of SAS, version 9.2 (SAS Institute Inc., Cary, NC). Statistical significance was defined at $P<0.05$.

\section{RESULTS}

\section{Microbiological Cultures and PCR-RFLP}

Composite milk samples were collected from 1,242 dairy cows during the first sample collection used to screen cows with subclinical mastitis caused by CNS. During the second sample collection, milk yield was measured and milk samples were collected at the quarter level from all cows $(\mathrm{n}=285)$ previously diagnosed with CNS IMI. Thus, milk samples from 1,140 mammary quarters were submitted to microbiological culture and milk composition and SCC. After microbiological culture, 141 CNS were isolated from milk samples. Only pure CNS isolates that could be recovered from the storage medium were submitted to speciation by PCR-RFLP. Hence, 108 isolates were identified at the species level and evaluated in this study.

Eleven CNS species were identified by PCR-RFLP at the mammary quarter level and results are completely described in a recently published study (Tomazi et al., 2014). Staphylococcus chromogenes was the most frequently isolated CNS species $(\mathrm{n}=80 ; 74.07 \%)$ from subclinical IMI at the quarter level. Three isolates $(2.78 \%)$ were identified as coagulase-negative S. aureus. Other CNS species identified by PCR-RFLP were $S$. saprophyticus $(\mathrm{n}=6)$, S. haemolyticus $(\mathrm{n}=5)$, S. simu- lans $(\mathrm{n}=4), S$. xylosus $(\mathrm{n}=3)$, S. capitis $(\mathrm{n}=2), S$. epidermidis $(\mathrm{n}=2)$, S. sciuri $(\mathrm{n}=1)$, S. cohnii $(\mathrm{n}=1)$, and $S$. hyicus $(\mathrm{n}=1)$.

\section{Milk Yield, Milk Composition, and SCC}

Milk yield, milk composition, and SCC at the species level from all CNS isolates are presented in Table 2. When evaluated as a group, mammary quarters infected with CNS had an average milk yield of 2.26 $\mathrm{kg} /$ milking and geometric mean SCC of 278,512 cells/ $\mathrm{mL}$. Staphylococcus chromogenes was the most prevalent CNS species isolated from mammary quarters with subclinical IMI, with an average milk yield of $2.31 \mathrm{~kg} /$ milking and geometric mean SCC of 277,164 cells/mL (Table 2).

Eight-two contralateral mammary quarters (41 pairs) were evaluated in this study. Milk yield, milk composition, and SCC from 41 mammary quarters with subclinical IMI caused by CNS as a group were compared with those of contralateral noninfected mammary quarters. Quarters with CNS subclinical IMI had higher geometric mean SCC $(306,106$ cells $/ \mathrm{mL})$ than their contralateral mammary quarters $(62,807$ cells/ $\mathrm{mL})$. We detected no effect $(P>0.05)$ of IMI caused by CNS on milk yield and composition. The average milk yield from a single milking was $2.281 \mathrm{~kg}$ for CNS infected quarters and $2.330 \mathrm{~kg}$ for noninfected quarters (Table 3).

After species identification, S. chromogenes was the only CNS species with a sufficient number of isolates to allow statistical evaluation at the contralateral mammary quarter level. Therefore, milk yield, milk 
Table 3. Milk yield, milk composition, and SCC of contralateral mammary quarters $(\mathrm{n}=82)$ both with $(\mathrm{n}=41)$ and without $(\mathrm{n}=41)$ subclinical IMI caused by CNS

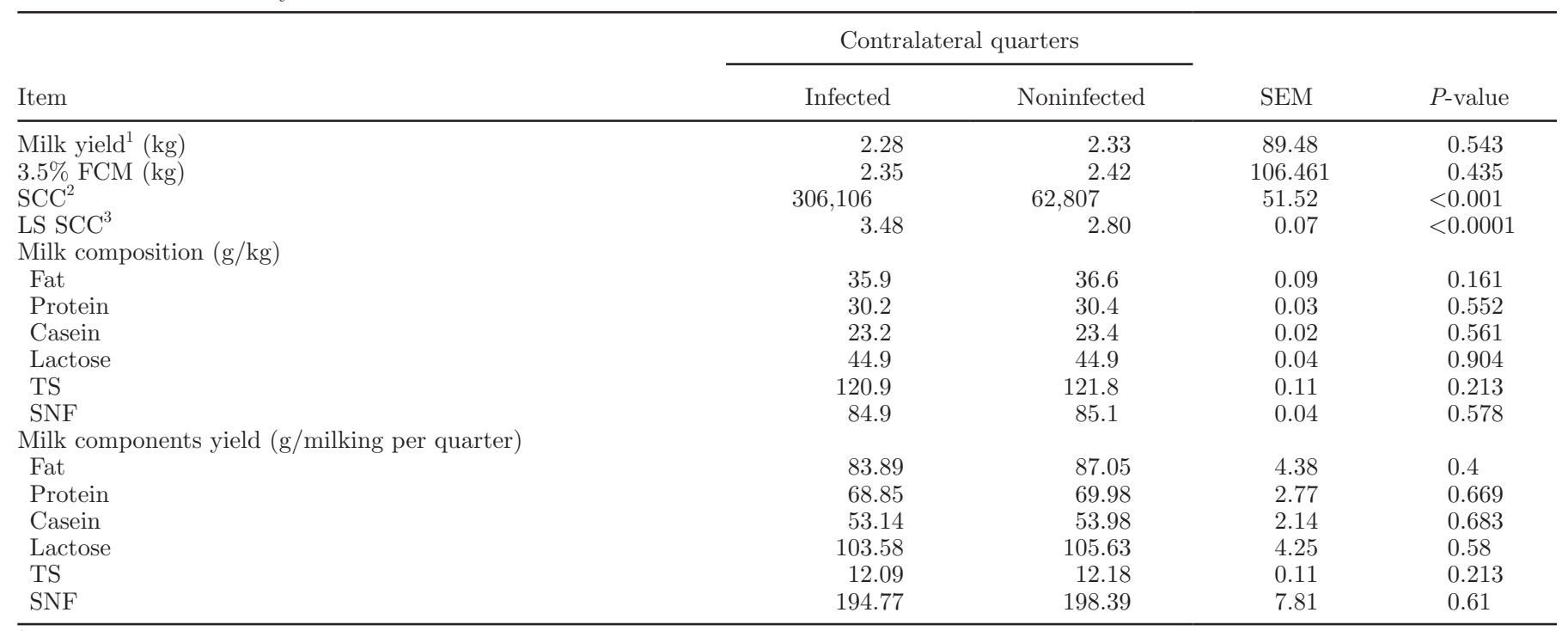

${ }^{1}$ Quarter milk yield $(\mathrm{kg})$ from a single milking.

${ }^{2}$ Average geometric mean SCC (cells $\left./ \mathrm{mL}\right)$.

${ }^{3}$ Natural logarithm-transformed SCC.

composition, and SCC from 31 mammary quarters with subclinical IMI caused by $S$. chromogenes were compared with their contralateral noninfected quarters. As expected, quarters infected with $S$. chromogenes had higher SCC $(315,300$ cells $/ \mathrm{mL})$ than noninfected contralateral quarters $(61,139 \mathrm{cell} / \mathrm{mL})$. However, we observed no effects $(P>0.05)$ of subclinical IMI caused by $S$. chromogenes on milk yield or composition (Table $4)$.

\section{DISCUSSION}

In this study, IMI caused by CNS as a group had no effect on milk yield or composition, but we observed

Table 4. Milk yield, milk composition, and SCC of contralateral mammary quarters $(\mathrm{n}=62)$ with $(\mathrm{n}=31)$ and without $(\mathrm{n}=31)$ subclinical IMI caused by Staphylococcus chromogenes

\begin{tabular}{|c|c|c|c|c|}
\hline \multirow[b]{2}{*}{ Variable } & \multicolumn{2}{|c|}{ Contralateral quarters } & \multirow[b]{2}{*}{ SEM } & \multirow[b]{2}{*}{$P$-value } \\
\hline & Infected & Noninfected & & \\
\hline Milk yield $^{1}(\mathrm{~kg})$ & 2.31 & 2.36 & 107.02 & 0.56 \\
\hline $\mathrm{SCC}^{2}$ & 315,300 & 61,139 & 54.79 & 0.003 \\
\hline $\mathrm{LS} \mathrm{SCC}^{3}$ & 3.50 & 2.79 & 0.07 & $<0.0001$ \\
\hline \multicolumn{5}{|c|}{ Milk composition $(\mathrm{g} / \mathrm{kg})$} \\
\hline Casein & 2.33 & 2.34 & 0.02 & 0.8 \\
\hline Lactose & 4.46 & 4.46 & 0.04 & 0.953 \\
\hline TS & 12.16 & 12.25 & 0.13 & 0.332 \\
\hline SNF & 8.46 & 8.48 & 0.05 & 0.721 \\
\hline \multicolumn{5}{|c|}{ Milk components yield ( $\mathrm{g} /$ milking per quarter) } \\
\hline Fat & 87.25 & 90.43 & 5.15 & 0.46 \\
\hline Protein & 70.37 & 70.94 & 3.38 & 0.838 \\
\hline
\end{tabular}

${ }^{1}$ Quarter milk yield $(\mathrm{kg})$ from a single milking.

${ }^{2}$ Average geometric mean SCC (cells $/ \mathrm{mL}$ ).

${ }^{3}$ Natural logarithm-transformed SCC. 
an increase in SCC by comparing contralateral mammary quarters. The SCC of CNS-infected quarters was approximately 5-fold higher than that observed for healthy mammary quarters. Recent studies have suggested that CNS species, especially host-adapted CNS, have similar capacity of adhesion in mammary cells as $S$. aureus, which stimulates the immune system of dairy cows, thereby increasing milk SCC (Supré et al., 2011). On the other hand, some CNS species have a lower degree of invasiveness into cells compared with $S$. aureus, and thus potentially cause less damage to the mammary gland secretory tissue (Taponen and Pyörälä, 2009). This pathogenic profile of some CNS species may explain the increase in SCC without a reduction in milk yield, as observed in the present study.

Some studies have reported that CNS, when considered as a whole group of mastitis pathogens, cause moderate increases of the SCC with values intermediate between those of healthy and $S$. aureus-infected mammary quarters (Supré et al., 2011). Conversely, other studies have reported that IMI caused by CNS can increase SCC to values $>600,000$ cells $/ \mathrm{mL}$ (Taponen et al., 2007). However, the effect of IMI caused by CNS on SCC can be species-specific, which could explain the variation in results among studies (Fry et al., 2014). Supré et al. (2011) reported that mammary quarters infected with $S$. chromogenes, S. simulans, and S. xylosus increased the SCC similar to that observed in IMI caused by $S$. aureus. Thorberg et al. (2009) described no differences in SCC between cows with subclinical IMI caused by $S$. chromogenes, S. epidermidis, and S. simulans, although these species have shown higher SCC than those of healthy cows. In this study, $S$. chromogenes was the only CNS species for which an accurate statistical analysis could be performed at the species level to evaluate the effect of subclinical IMI on milk yield and composition. The milk yield and composition of dairy cows with subclinical IMI caused by other CNS species in this study was not evaluated because of the low frequency of isolation.

Although S. chromogenes-infected quarters had increased SCC, no effect on milk yield and composition was observed. The average SCC of mammary quarters infected by $S$. chromogenes $(315,300$ cells $/ \mathrm{mL})$ in our study was higher than average SCC reported by Sampimon et al. (2009), wherein the SCC of quarters infected with the same pathogen was 192,000 cells/mL. As reported by Taponen and Pyörälä (2009), S. chromogenes has similar adhesiveness capacity on the mammary secretory tissue as $S$. aureus but lower invasive potential in mammary cells. In addition, IMI caused by $S$. chromogenes promotes the release of a protease enzyme with a cytotoxic effect, which stimulates the infiltration of neutrophils to the inflammation site (Zhang and Maddox, 2000). These pathogenic characteristics suggest that $S$. chromogenes has virulence factors that stimulate the release of polymorphonuclear leukocytes into the mammary gland, which leads to the increase of milk SCC.

Although several studies have been performed to determine the effect of CNS IMI on milk yield, the results remain controversial. The results of our study showed that IMI caused by CNS as a group or by $S$. chromogenes had no effect on milk yield using contralateral quarter comparison. Other studies have also reported the lack of effect of CNS IMI on milk yield of dairy cows (Paradis et al., 2010; Hertl et al., 2014). Pearson et al. (2013) reported no effect of CNS IMI on milk yield of heifers during their first 200 DIM by comparing monozygotic twins, in which one twin had a naturally occurring IMI detected at the first milking after calving and the other twin did not.

Few studies have reported a significant negative effect of mastitis caused by CNS on milk yield (Timms and Schultz, 1987; Gröhn et al., 2004). De Vliegher et al. (2005), evaluating data from approximately 14,000 heifers, reported an increase in SCC measured between 5 and 14 DIM, which had a negative effect on testday milk production and SCC throughout the first lactation. Conversely, studies have reported that cows with IMI caused by CNS had greater milk yields than healthy cows (Wilson et al., 1997; Schukken et al., 2009; Piepers et al., 2010). A recent study evaluated the effect of IMI caused by CNS in early lactating heifers on milk yield using a series of statistical models that included potential confounding and intermediate variables (Piepers et al., 2013). After correction for several confounders, those models showed higher daily milk yield from heifers with subclinical CNS IMI $(2.0 \mathrm{~kg} / \mathrm{d})$ than from noninfected heifers. That study suggested that the higher milk yield found in heifers with CNS IMI might be attributed to a protective effect of the current infection against a subsequent infection caused by a major pathogen. However, losses in milk yield may be underestimated when infected cows are compared with groups of healthy cows rather than with their production before the IMI (Pyörälä and Taponen, 2009). Thus, a plausible hypothesis is that high-producing cows are at greater risk of acquiring a CNS IMI than cows with lower milk production.

Some CNS species can have different epidemiology profiles and may cause greater milk losses than others. In the study of Thorberg et al. (2009), cows with nonpersistent subclinical IMI caused by $S$. simulans had lower daily milk yield than healthy cows or cows with persistent subclinical IMI caused by $S$. chromogenes, S. epidermidis, or $S$. simulans. In the same study, cows with nonpersistent subclinical IMI caused by $S$. epider- 
midis had lower milk yield than cows with persistent subclinical IMI caused by S. chromogenes and S. simulans. Because of the low frequency of most CNS species isolated in this study, the only species in which it was possible to evaluate the effect of IMI on milk yield was $S$. chromogenes, in which the milk yield of infected cows was not affected.

In our study, the subclinical IMI caused by CNS did not change milk solids contents. Coulon et al. (2002) also reported no effect of CNS IMI on milk yield but observed an increased SCC $(+0.37 \mathrm{log} / \mathrm{mL})$ and a slight decrease in lactose concentration $(-1.8 \mathrm{~g} / \mathrm{kg})$ of CNS-infected dairy cows. Lactose and SCC are the most sensitive parameters to infection of the mammary gland, and these changes reflect the udder immune responses against mastitis-causing pathogens (Coulon et al., 2002). In our study, although CNS IMI increased SCC, it did not decrease the concentration of lactose.

One possible limitation of the present study is that the microbiological culture procedure was only performed by inoculation of milk samples onto blood agar plates and incubation under aerobic conditions (Hogan et al., 1999). This methodology excluded the isolation of some pathogens, such as Mycoplasma spp., that require specific identification microbiological procedures (Fox, 2012). However, considering that IMI caused by Mycoplasma spp. are usually associated with a significant increase in the SCC (González and Wilson, 2003), we suggest that this limitation was controlled in our study because a threshold of $<200,000$ cells $/ \mathrm{mL}$ was used for control mammary quarters.

Another limitation of our study was the evaluation of milk yield and composition based on a single milking during the day. Milk yield and composition might vary between morning and evening milkings, especially due to variation that normally occurs in the interval between morning and evening milkings among herds. If cows were milked at 12 -h intervals, the variation in milk yield and content between milkings would be negligible, but this is not practical on most farms. However, all evaluations regarding milk yield and composition in this study were performed during the evening milking, which may have reduced this limitation.

Comparison of infected and healthy mammary quarters from different cows can be influenced by factors that may vary among cows and herds, such as genetic potential of milk production, cows' physiological conditions, environmental challenge, seasonal factors, and feed management. The results of this study suggest that the evaluation of CNS IMI by comparison of contralateral mammary quarters can optimize the individual cow effect in the data analysis and eliminate confounding factors. However, the method of comparison of contralateral mammary quarters used in our study may have some limitations. We did not evaluate the chronicity of IMI caused by CNS, because the presence of subclinical mastitis was defined based on 2 milk samples collected within $14 \mathrm{~d}$. As described previously, the persistence of IMI caused by CNS could affect milk yield according to the causative species (Thorberg et al., 2009). In addition, we also did not control whether the uninfected contralateral quarter recently cleared an IMI, which could also affect comparison of contralateral mammary quarters in our study.

Even though we observed no effect of IMI caused by CNS on milk yield and composition in this study, mammary quarters infected with CNS had significantly higher SCC than healthy quarters. Other studies have also described a significant increase of SCC in cows with subclinical CNS IMI (Schukken et al., 2009; Fry et al., 2014). Dairy farmers with high prevalence of subclinical IMI caused by CNS may be penalized in milk quality-based payment systems. Because of the high prevalence of CNS in modern dairy herds, the potential to cause persistent infection, antibiotic resistance, and significant increases in SCC efforts should be monitored to reduce the prevalence of this group of pathogens in dairy herds.

\section{CONCLUSIONS}

The subclinical IMI caused by CNS group increased SCC but did not change milk yield or milk solids contents of dairy cows evaluated at the contralateral quarter level. Within CNS group, S. chromogenes was the only species evaluated at contralateral quarter level; similarly to CNS as a group, S. chromogenes increased SCC but did not affect milk yield or composition of infected mammary quarters.

\section{ACKNOWLEDGMENTS}

We are grateful to the Fundação de Amparo à Pesquisa do Estado de São Paulo (FAPESP, Brazil) for a scholarship award (2011/04063-1) and research funding (2011/14284-5). We also thank José Garcia Franchini and Lucineia Mestieri (Qualileite Milk Quality Laboratory, School of Veterinary Medicine and Animal Science, University of Sao Paulo, Pirassununga, Brazil) for their assistance with laboratory analysis.

\section{REFERENCES}

Andersen, S., I. R. Dohoo, R. Olde Riekerink, and H. Stryhn. 2010. Diagnosing intramammary infections: Evaluating expert opinions on the definition of intramammary infection using conjoint analysis. J. Dairy Sci. 93:2966-2975.

Capurro, A., K. Artursson, K. P. Waller, B. Bengtsson, H. EricssonUnnerstad, and A. Aspán. 2009. Comparison of a commercialized 
phenotyping system, antimicrobial susceptibility testing, and tuf gene sequence-based genotyping for species-level identification of coagulase-negative staphylococci isolated from cases of bovine mastitis. Vet. Microbiol. 134:327-333.

Coulon, J. B., P. Gasqui, J. Barnouin, A. Ollier, P. Pradel, and D. Pomies. 2002. Effect of mastitis and related-germ on milk yield and composition during naturally occurring udder infections in dairy cows. Anim. Res. 51:383-393.

De Vliegher, S., H. W. Barkema, H. Stryhn, G. Opsomer, and A. de Kruif. 2005. Impact of early lactation somatic cell count in heifers on milk yield over the first lactation. J. Dairy Sci. 88:938-947.

Dohoo, I. R., J. Smith, S. Andersen, D. F. Kelton, and S. Godden. 2011. Diagnosing intramammary infections: Evaluation of definitions based on a single milk sample. J. Dairy Sci. 94:250-261.

Fox, L. K. 2012. Mycoplasma mastitis: Causes, transmission, and control. Vet. Clin. North Am. Food Anim. Pract. 28:225-237.

Fry, P. R., J. R. Middleton, S. Dufour, J. Perry, D. Scholl, and I. Dohoo. 2014. Association of coagulase-negative staphylococcal species, mammary quarter milk somatic cell count, and persistence of intramammary infection in dairy cattle. J. Dairy Sci. 97:4876-4885.

Goh, S. H., Z. Santucci, W. E. Kloos, M. Faltyn, C. G. George, D. Driedger, and S. M. Hemmingsen. 1997. Identification of Staphylococcus species and subspecies by the chaperonin 60 gene identification method and reverse checkerboard hybridization. J. Clin. Microbiol. 35:3116-3121.

González, R. N., and D. J. Wilson. 2003. Mycoplasma mastitis in dairy herds. Vet. Clin. North Am. Food Anim. Pract. 19:199-221.

Gröhn, Y. T., D. J. Wilson, R. N. Gonzalez, J. A. Hertl, H. Schulte, G. Bennett, and Y. H. Schukken. 2004. Effect of pathogen-specific clinical mastitis on milk yield in dairy cows. J. Dairy Sci. 87:3358-3374.

Hertl, J. A., Y. H. Schukken, F. L. Welcome, L. W. Tauer, and Y. T. Grohn. 2014. Pathogen-specific effects on milk yield in repeated clinical mastitis episodes in Holstein dairy cows. J. Dairy Sci. 97:1465-1480.

Hogan, J. S., R. N. Gonzalez, R. J. Harmon, S. C. Nickerson, S. P. Oliver, J. W. Pankey, and K. L. Smith, ed. 1999. Laboratory Handbook on Bovine Mastitis. 2nd edition. National Mastitis Council Inc., Madison, WI.

IDF (International Dairy Federation). 1995. Milk-Enumeration of somatic cell. IDF Standard 148:1995. IDF, Brussels, Belgium.

Oliver, S. P., R. N. Gonzalez, J. S. Hogan, B. M. Jayarao, and W. E. Owens, eds. 2004. Microbiological Procedures for the Diagnosis of Bovine Udder Infection and Determination of Milk Quality. 4th ed. National Mastitis Council Inc., Verona, WI.

Paradis, M. Ė., É. Bouchard, D. T. Scholl, F. Miglior, and J. P. Roy. 2010. Effect of nonclinical Staphylococcus aureus or coagulase-negative staphylococci intramammary infection during the first month of lactation on somatic cell count and milk yield in heifers. J. Dairy Sci. 93:2989-2997.

Pearson, L. J., J. H. Williamson, S. A. Turner, S. J. Lacy-Hulbert, and J. E. Hillerton. 2013. Peripartum infection with Streptococcus uberis but not coagulase-negative staphylococci reduced milk production in primiparous cows. J. Dairy Sci. 96:158-164.

Piepers, S., G. Opsomer, H. W. Barkema, A. de Kruif, and S. De Vliegher. 2010. Heifers infected with coagulase-negative staphylococci in early lactation have fewer cases of clinical mastitis and higher milk production in their first lactation than noninfected heifers. J. Dairy Sci. 93:2014-2024.

Piepers, S., Y. H. Schukken, P. Passchyn, and S. De Vliegher. 2013. The effect of intramammary infection with coagulase-negative staphylococci in early lactating heifers on milk yield throughout first lactation revisited. J. Dairy Sci. 96:5095-5105.

Piessens, V., S. De Vliegher, B. Verbist, G. Braem, A. Van Nuffel, L. De Vuyst, M. Heyndrickx, and E. Van Coillie. 2012. Intra-species diversity and epidemiology varies among coagulase-negative staphylococcus species causing bovine intramammary infections. Vet. Microbiol. 155:62-71.

Pyörälä, S., and S. Taponen. 2009. Coagulase-negative staphylococciEmerging mastitis pathogens. Vet. Microbiol. 134:3-8.

Sambrook, J., and D. W. Russell. 2001. Molecular Cloning: A Laboratory Manual. 3rd ed. Cold Spring Harbor Laboratory Press, Cold Spring Harbor, NY.

Sampimon, O. C., H. W. Barkema, I. M. G. A. Berends, J. Sol, and T. J. G. M. Lam. 2009. Prevalence and herd-level risk factors for intramammary infection with coagulase-negative staphylococci in Dutch dairy herds. Vet. Microbiol. 134:37-44.

Santos, O. C. D., E. M. Barros, M. Brito, M. D. D. Bastos, K. R. N. dos Santos, and M. Giambiagi-DeMarval. 2008. Identification of coagulase-negative staphylococci from bovine mastitis using RFLP-PCR of the groEL gene. Vet. Microbiol. 130:134-140.

Schukken, Y. H., R. N. González, L. L. Tikofsky, H. F. Schulte, C. G. Santisteban, F. L. Welcome, G. J. Bennett, M. J. Zurakowski, and R. N. Zadoks. 2009. CNS mastitis: Nothing to worry about? Vet. Microbiol. 134:9-14.

Schukken, Y. H., D. J. Wilson, F. Welcome, L. Garrison-Tikofsky, and R. N. Gonzalez. 2003. Monitoring udder health and milk quality using somatic cell counts. Vet. Res. 34:579-596.

Supré, K., F. Haesebrouck, R. N. Zadoks, M. Vaneechoutte, S. Piepers, and S. De Vliegher. 2011. Some coagulase-negative staphylococcus species affect udder health more than others. J. Dairy Sci. 94:2329-2340

Taponen, S., J. Koort, J. Björkroth, H. Saloniemi, and S. Pyörälä. 2007. Bovine intramammary infections caused by coagulase-negative staphylococci may persist throughout lactation according to amplified fragment length polymorphism-based analysis. J. Dairy Sci. 90:3301-3307.

Taponen, S., and S. Pyörälä. 2009. Coagulase-negative staphylococci as cause of bovine mastitis - Not so different from Staphylococcus aureus? Vet. Microbiol. 134:29-36.

Taponen, S., H. Simojoki, M. Haveri, H. D. Larsen, and S. Pyörälä. 2006. Clinical characteristics and persistence of bovine mastitis caused by different species of coagulase-negative staphylococci identified with API or AFLP. Vet. Microbiol. 115:199-207.

Thorberg, B. M., M. L. Danielsson-Tham, U. Emanuelson, and K. Persson Waller. 2009. Bovine subclinical mastitis caused by different types of coagulase-negative staphylococci. J. Dairy Sci. 92:4962-4970.

Timms, L. L., and L. H. Schultz. 1987. Dynamics and significance of coagulase-negative staphylococcal intramammary infections. J. Dairy Sci. 70:2648-2657.

Tomazi, T., J. L. Gonçalves, J. R. Barreiro, P. A. C. Braga, L. F. Prada e Silva, M. N. Eberlin, and M. V. dos Santos. 2014. Identification of coagulase-negative staphylococci from bovine intramammary infection by matrix-assisted laser desorption ionization-time of flight mass spectrometry. J. Clin. Microbiol. 52:1658-1663.

Wilson, D. J., R. N. Gonzalez, and H. H. Das. 1997. Bovine mastitis pathogens in New York and Pennsylvania: Prevalence and effects on somatic cell count and milk production. J. Dairy Sci. 80:2592-2598.

Zhang, S. L., and C. W. Maddox. 2000. Cytotoxic activity of coagulase-negative staphylococci in bovine mastitis. Infect. Immun. 68:1102-1108 